\title{
Beiradeiros: viver à beira no extremo sul da Bahia
}

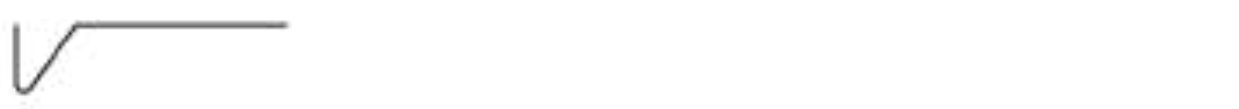

Ananda da Luz Ferreira ${ }^{1}$

Herbert Toledo Martins ${ }^{2}$

\begin{abstract}
No relento é cada farol que alumia, energia não tinha "não tinha teto, não tinha nada!"

É a arquitetura do madeirite e do papelão, ou a lona que escapa do caminhão

a cobrir os sonhos nessa beira, quanta provação!

"Ninguém podia fazer pipi, por que banheiro..." o mato é logo ali

Canta o pneu, of farol pisca, relur, alumia

Viajantes passam, todo mundo olha, mas ninguém vê o Beiradeiro e sua cria

$E$ seus sonhos de melhores dias espremidos entre a cerca e a rodovia

(Oneide Andrade da Costa)
\end{abstract}

À beira da BR-101, entre as cercas das grandes fazendas e a estrada moram famílias em condições peculiares, numa situação de invisibilidade perante a sociedade e ao Estado. São moradores da cidade de Teixeira de Freitas, Extremo Sul da Bahia, que ocupam irregularmente as faixas de terras públicas geridas pelo Departamento Nacional Infraestrutura e Transporte (DNIT). Essa população, denominada pela pesquisa de Beiradeiros, são dissimulados por quem atravessa essa estrada diariamente e pelo Estado, mesmo que componha um número significativo de famílias moradoras da beira do asfalto, são 68 nos $26 \mathrm{~km}$ de estrada que fazem parte do município onde a pesquisa é realizada. A

1 Fotógrafa da pesquisa. Mestre pelo Programa de Pós-Graduação em Ensino e Relações Étnico-Raciais pelo PPGER/UFSB. Pedagoga e membro do Grupo de Pesquisa em Criminalidade e Segurança Social (GPECS/CNPQ) e do PIPEC - Janaina Aparecida. E-mail: anandaluzananda@gmail.com

2 Professor Doutor do Programa de Pós-Graduação em Estado e Sociedade da Universidade PPGES/UFSB, coordenador do Grupo de Pesquisa em Criminalidade e Segurança Social (GPECS/CNPQ). E-mail: herbert.ufrb@gmail.com 
invisibilidade atravessa os modos de vidas dessas pessoas, pois vivem de forma adversa no que diz respeito aos seus direitos e acesso aos serviços públicos.

O presente ensaio fotográfico é fruto da pesquisa de campo "Beiradeiros: conflitos, vulnerabilidade e exclusão social no Extremo Sul da Bahia" que iniciou em setembro de 2018 e se encontra em andamento. A investigação, que tem como objetivo visibilizar a população Beiradeira, foi dividida em duas etapas: a primeira de natureza quantitativa na qual foram aplicados questionários sociodemográficos que apontou dados sobre o perfil dos moradores da faixa de terra a longo da BR-101 no município de Teixeira de Freitas e, concomitantemente, realizou-se os registros fotográficos com câmera digital; a segunda etapa, que está em andamento, aborda qualitativamente dados sobre os modos de vida dos Beiradeiros por intermédio da pesquisa etnográfica e de caráter interdisciplinar, o projeto conta com pesquisadores das áreas da saúde, da educação, do direito e das ciências sociais. Diante desse contexto emerge a investigação sobre os Beiradeiros, na qual a nomeação da categoria reflete aos dados da pesquisa, pois foi uma constante se autodenominarem "moradores da beira" porque se localizam à beira da estrada e à beira das grandes fazendas de agropecuária e eucalipto do município.

Nessa perspectiva, dados apontaram que essa categoria se unifica pelas condições que estão sujeitos no que tange as suas moradias, pois não tem direito a posse de suas casas porque suas terras pertencem ao Estado. Por não serem residências regularizadas não há acesso as condições básicas de sobrevivência como energia elétrica e saneamento básico. Durante a entrevista foi constatado que 25 casas não possuem energia elétrica e 23 casas acessam energia por concessão de fazendeiros vizinhos que recebem dinheiro pelo fornecimento, as outras 20 residências possuem energia por intermédio do vizinho, placa fotovoltaica ou geradores. Ao recolhermos dados sobre saneamento básico foi constatado que nenhuma residência possui coleta de lixo, tratamento de água e rede de esgoto. Das casas entrevistadas 41,3\% não possuem sanitários ou buracos para dejeções, sendo que "o banheiro é o mato" como disseram alguns entrevistados. O acesso a água ocorre por armazenamento que recolhem dos rios e lagos existentes no local, uma pequena porcentagem tem poços artesianos ou coletam água da chuva. Economicamente, os Beiradeiros, vivem de políticas públicas governamentais e/ou da comercialização do que produzem em suas terras como mandioca, urucum, pimenta do reino, entre outros produtos sazonais (FERREIRA e MARTINS, 2019 e COSTA, 2020). 
A pesquisa e o ensaio fotográfico vêm descortinando as condições e o modo de vida Beiradeiro a partir de questões como: Quem são essas pessoas? Como elas satisfazem as suas necessidades básicas de sobrevivência? Como é viver na beira da estrada? De acordo com Cândido (1964, p. 31), cada sociedade, cada agrupamento humano enfrenta, em algum momento de sua existência, a equação entre o ajuste ao meio e a organização social necessária à subsistência. Assim, há dois ajustamentos essenciais ao equilíbrio entre necessidades e recursos, a saber: "1) a descoberta de soluções que permitam explorar o meio físico para obter recursos de subsistência; 2) o estabelecimento de uma organização social compatível com elas".

As imagens ilustram os dados que anunciam quem são os Beiradeiros e contribui como narrativa para além dos números que evidenciam seus modos de vida, ou seja, como provoca Oliveira e Júnior (2019), a fotografia tem caráter narrativo e pode ser utilizada para além de uma apêndice de texto escrito e sim como uma seleção do campo realizada pela fotógrafa que faz um recorte do real (MONTEIRO, 2006). Portanto, o presente ensaio fotográfico pretende apresentar os Beiradeiros e suas formas de viver e, dessa maneira, compreender como que eles se organizam para garantir a suas sobrevivências. A pesquisa tem como principal preocupação as relações entre o desenvolvimento econômico do Extremo Sul da Bahia e a produção de desigualdades e vulnerabilidades sociais cujas externalidades negativas podem ser visualizadas nas fotos a seguir, que expressam o caráter interdisciplinares da pesquisa que tem investigações sobre saúde, infância, o acesso dessa população às políticas sociais de proteção, promoção e inclusão social. 


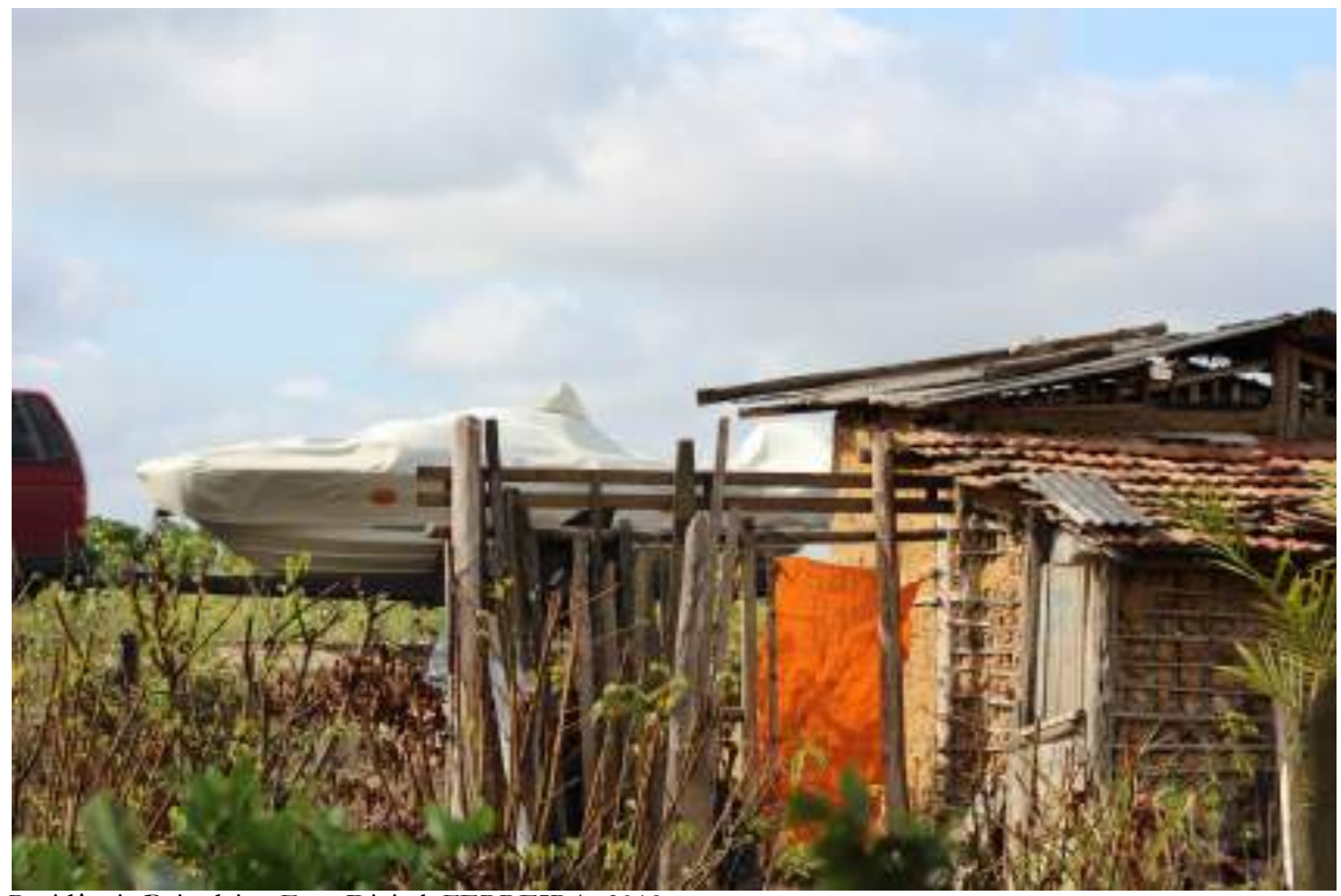

Residência Beiradeira. Foto Digital. FERREIRA, 2019.

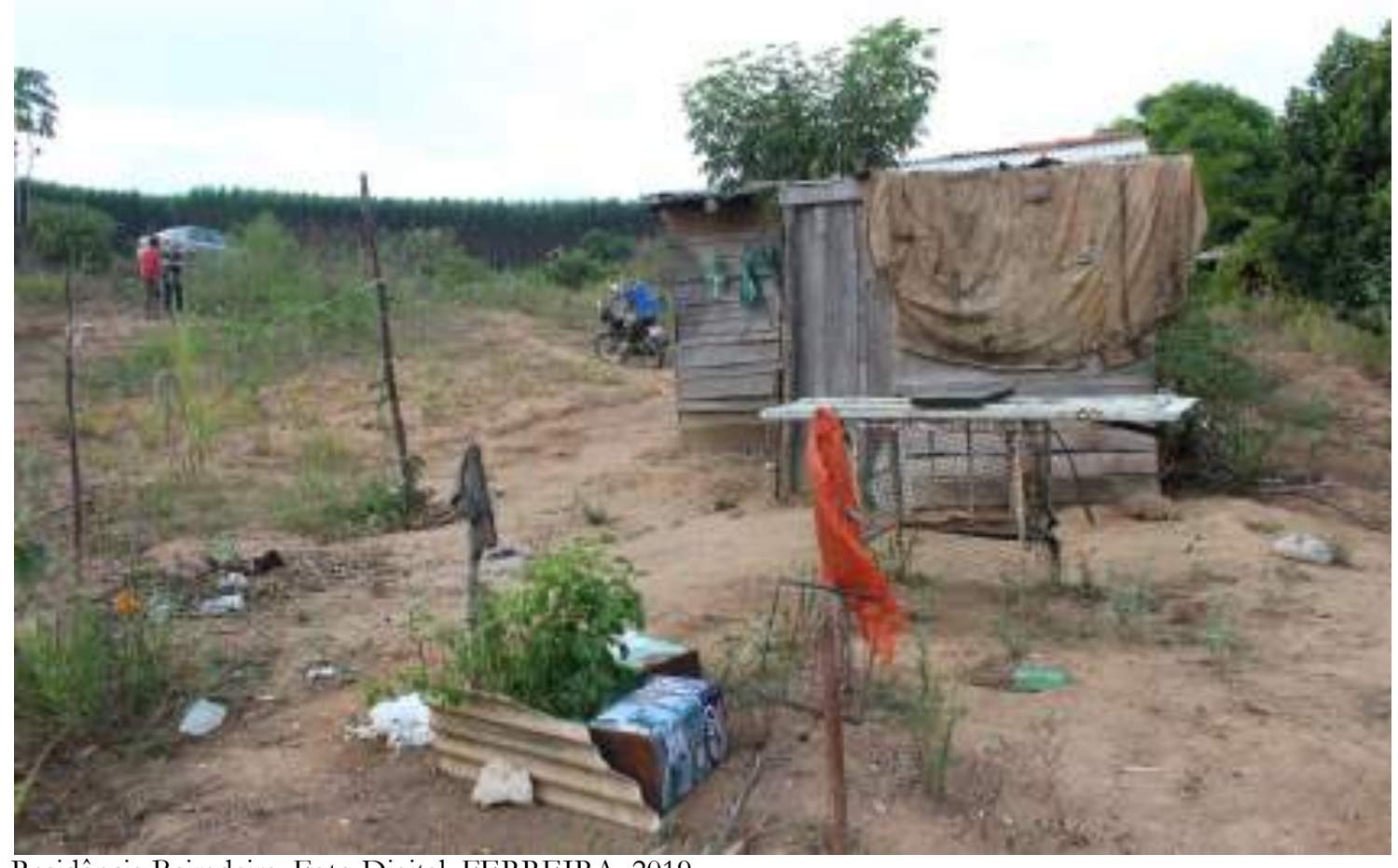

Residência Beiradeira. Foto Digital. FERREIRA, 2019. 


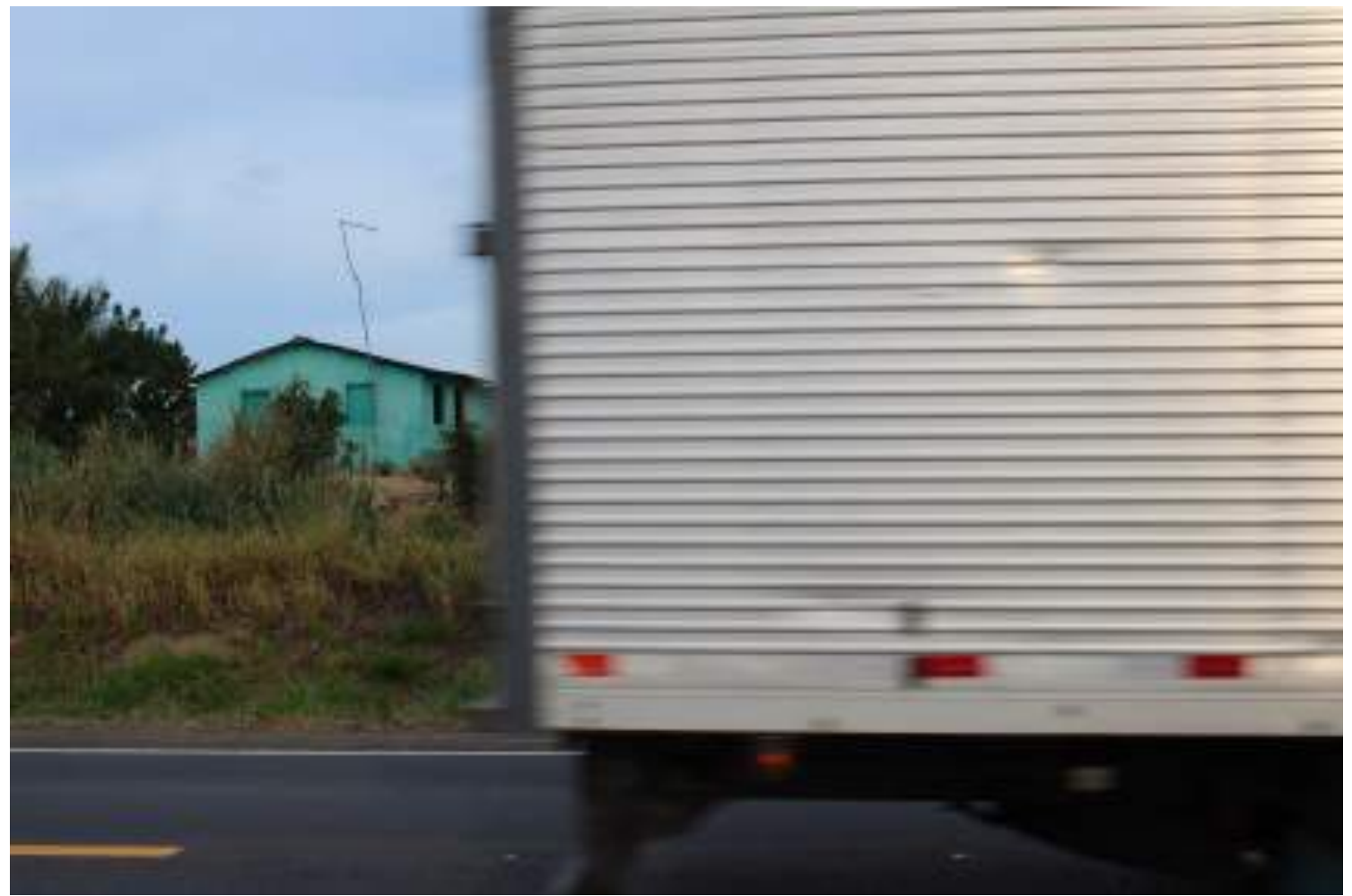

Residência Beiradeira. Foto Digital. FERREIRA, 2019.

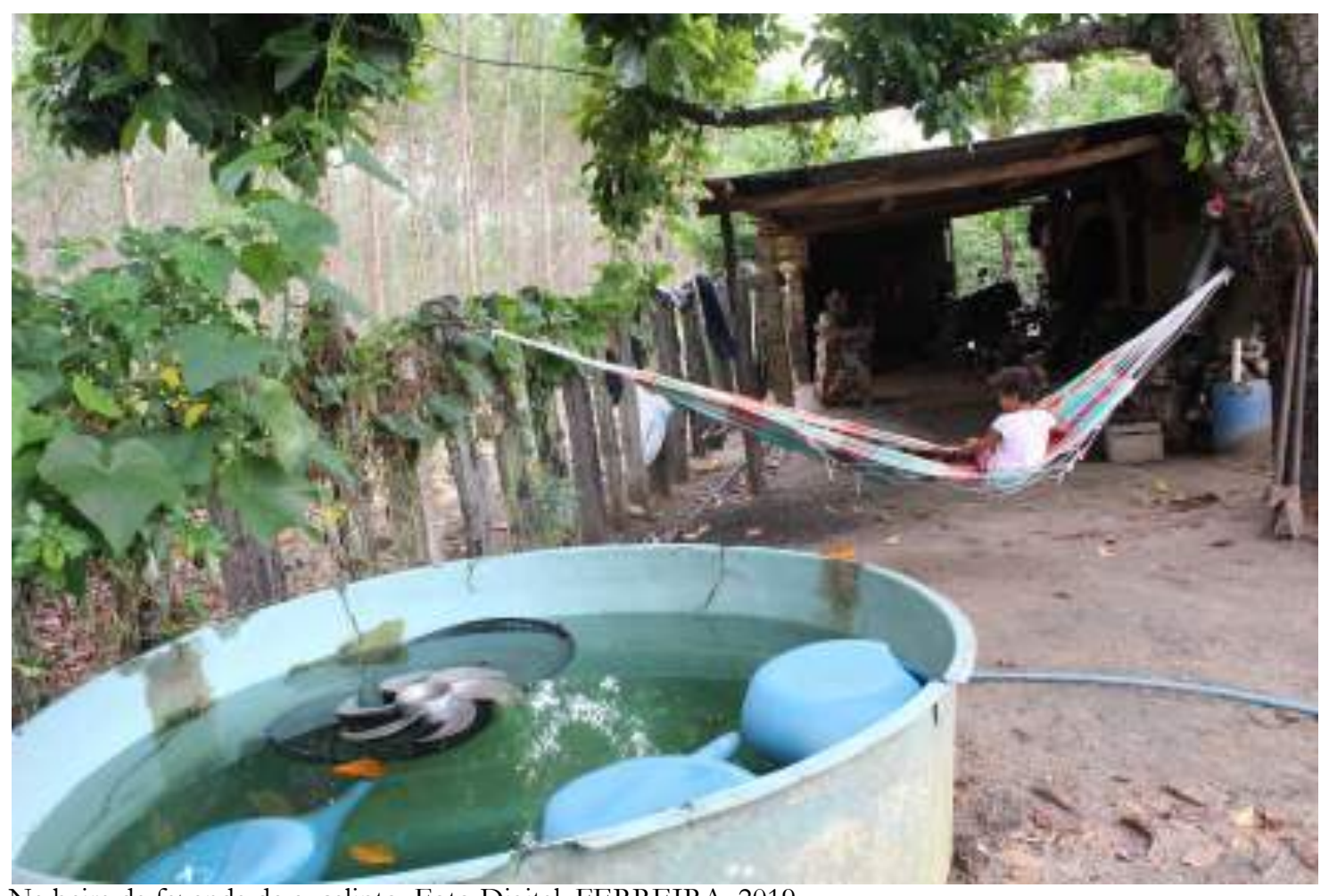

Na beira da fazenda de eucalipto. Foto Digital. FERREIRA, 2019. 


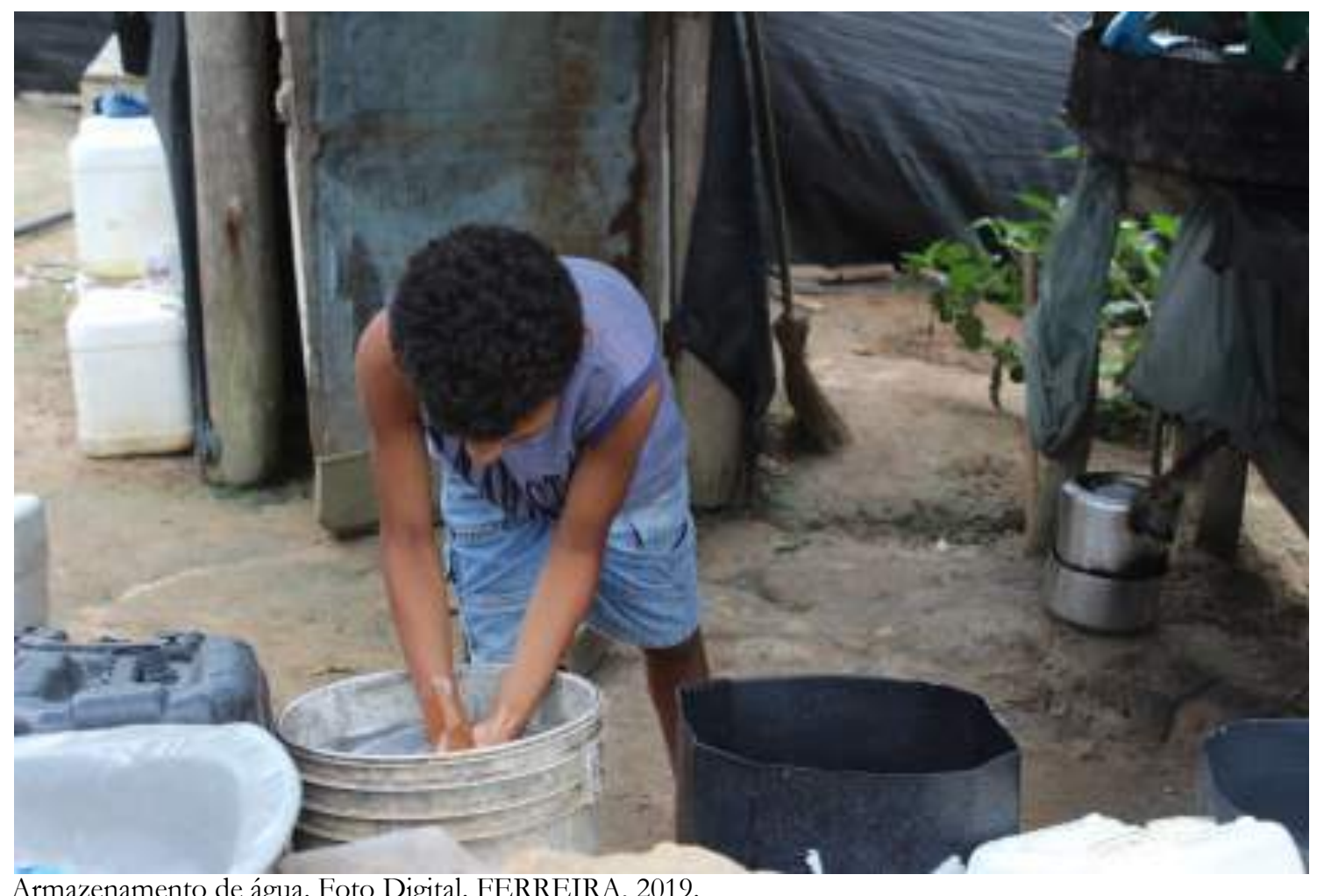

Armazenamento de água. Foto Digital. FERREIRA, 2019.

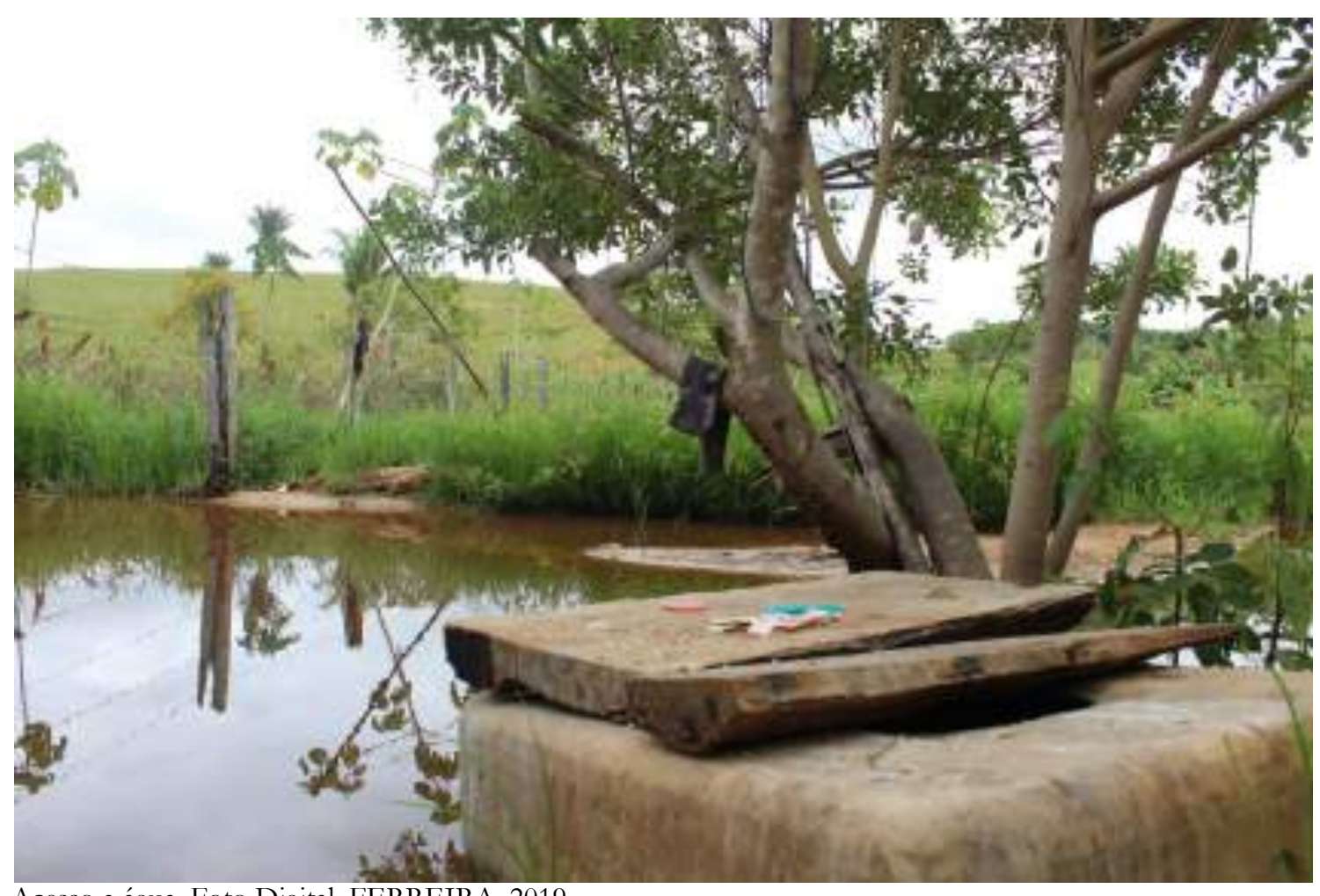

Acesso a água. Foto Digital. FERREIRA, 2019. 


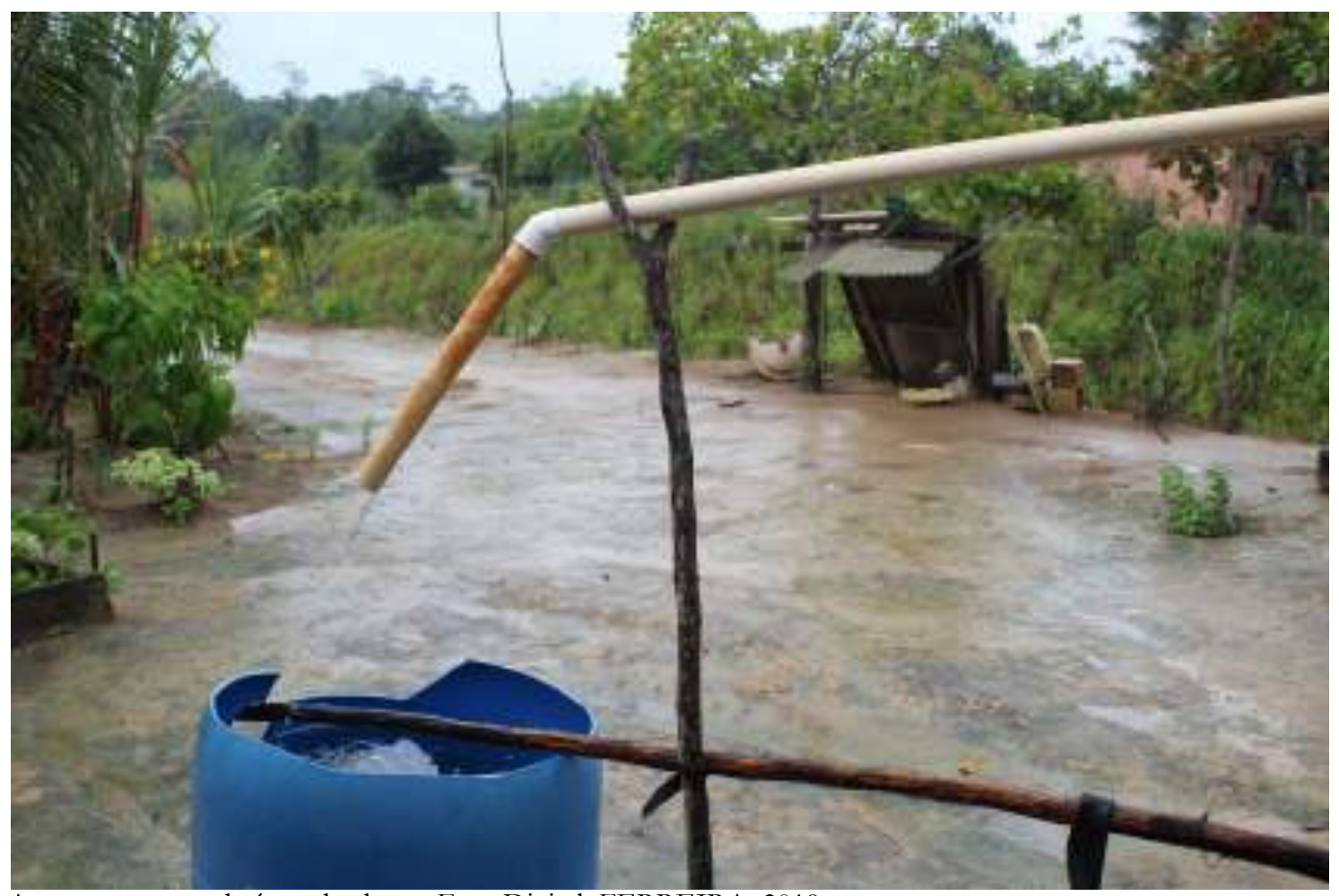

Armazenamento de água da chuva. Foto Digital. FERREIRA, 2019.

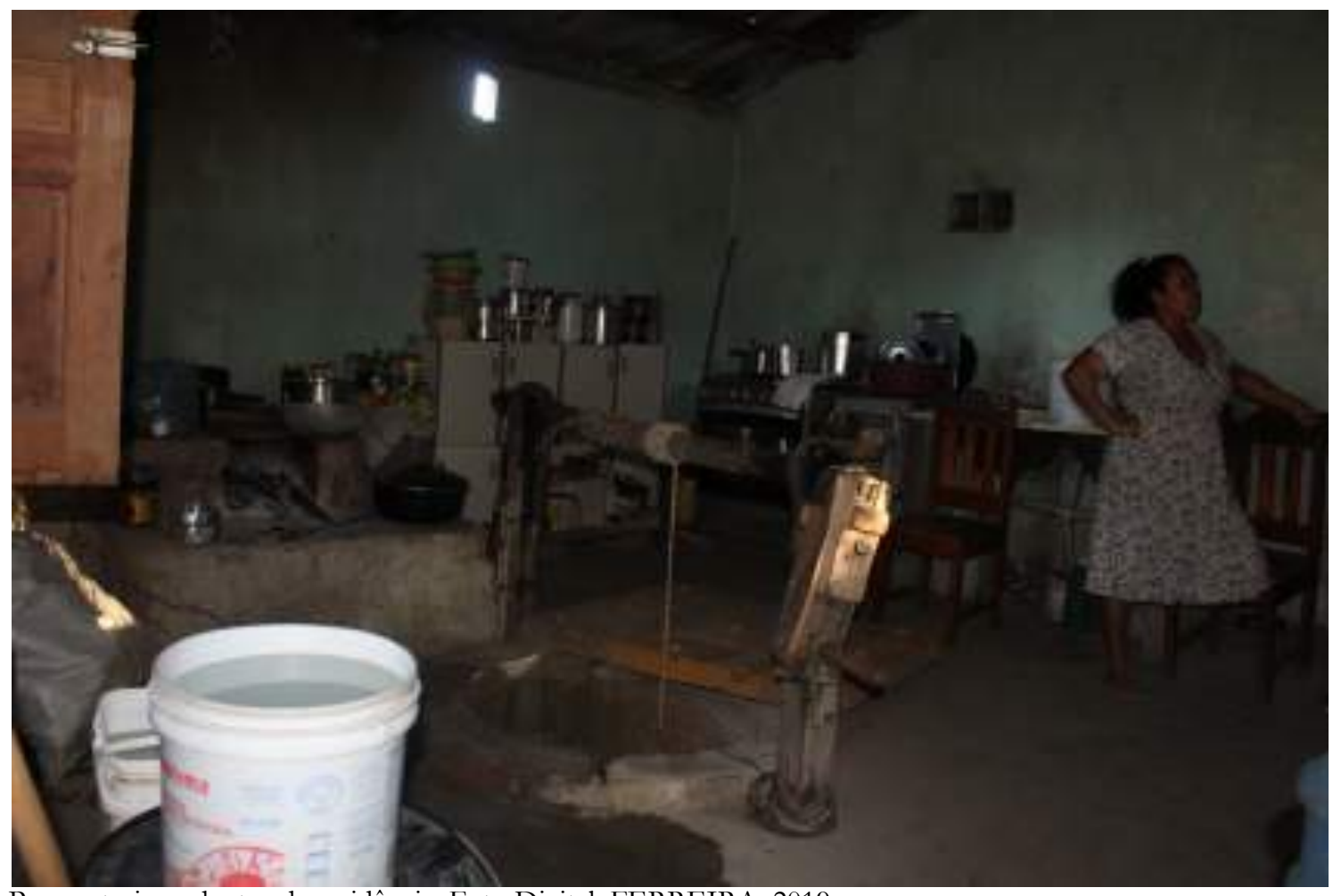

Poço artesiano dentro da residência. Foto Digital. FERREIRA, 2019. 


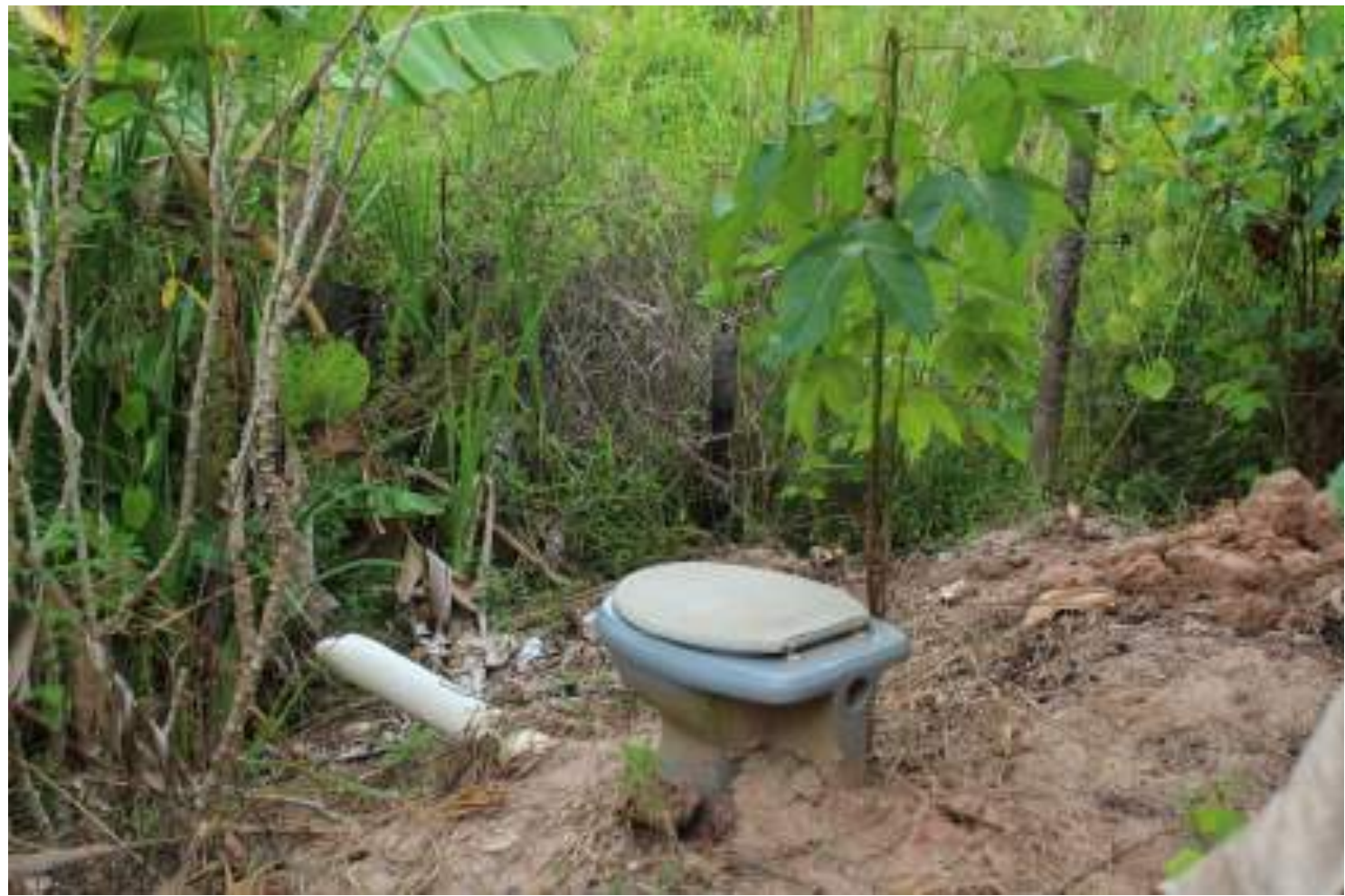

Banheiro a céu aberto. Foto Digital. FERREIRA, 2019.

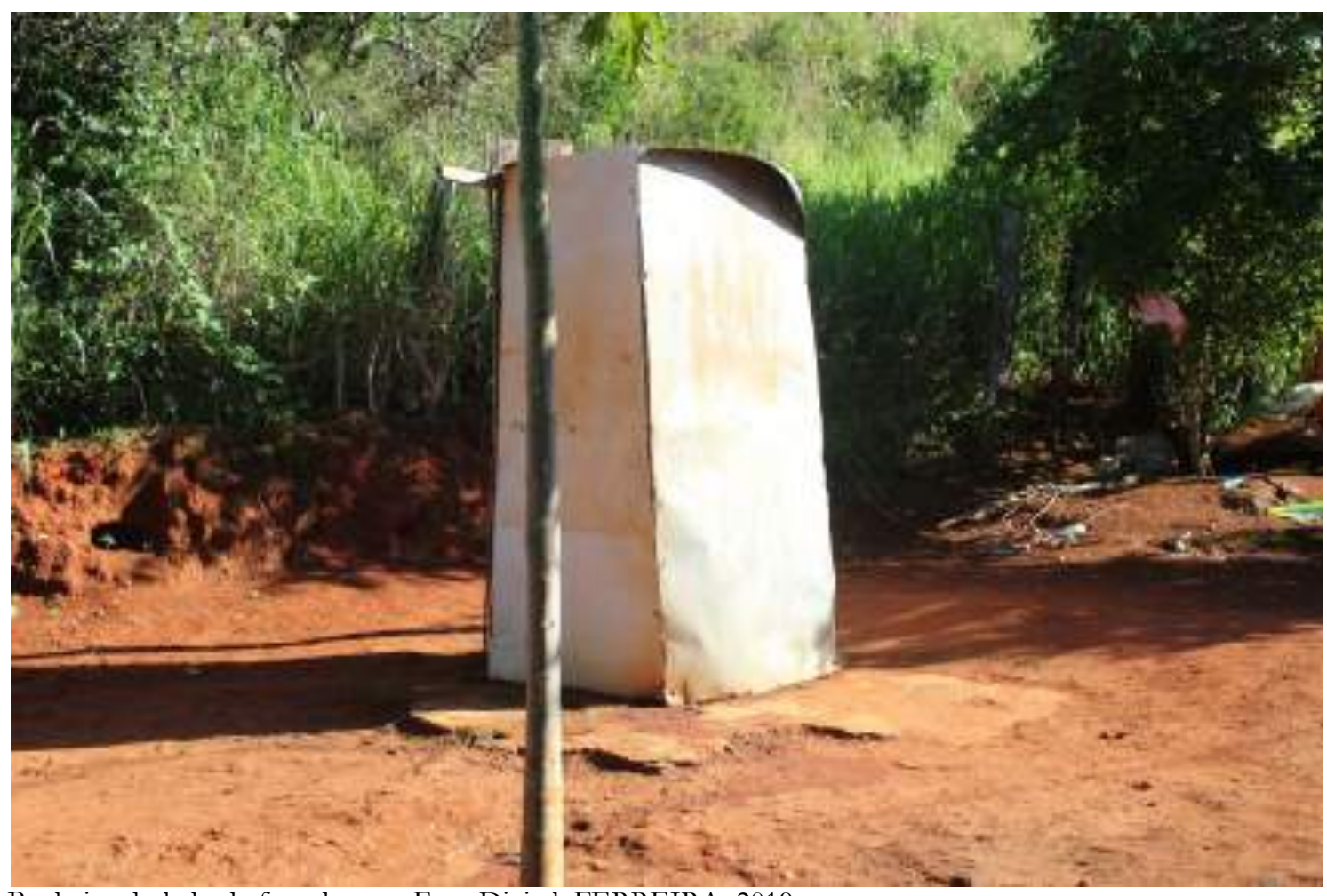

Banheiro do lado de fora da casa. Foto Digital. FERREIRA, 2019 


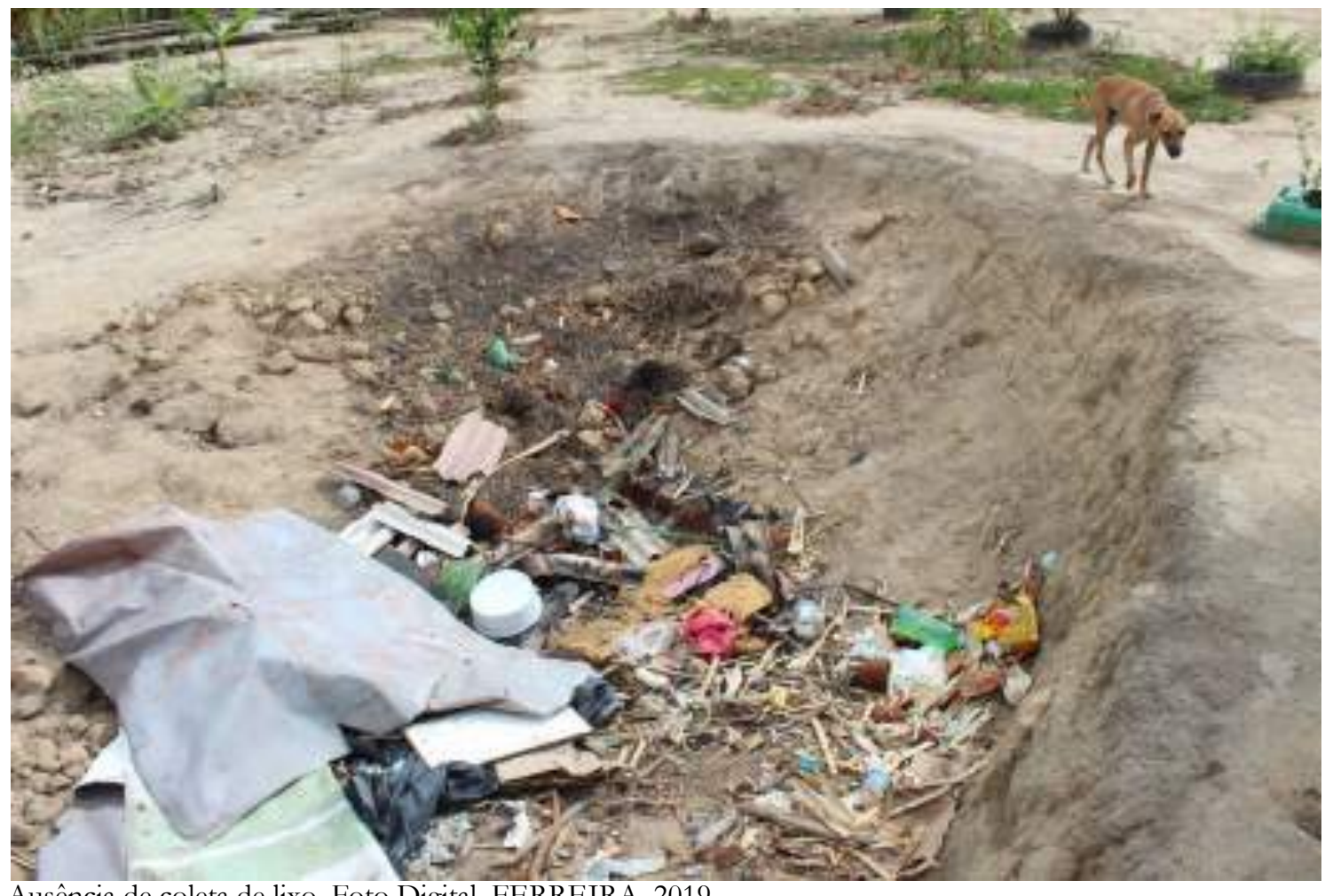

Ausência de coleta de lixo. Foto Digital. FERREIRA, 2019.

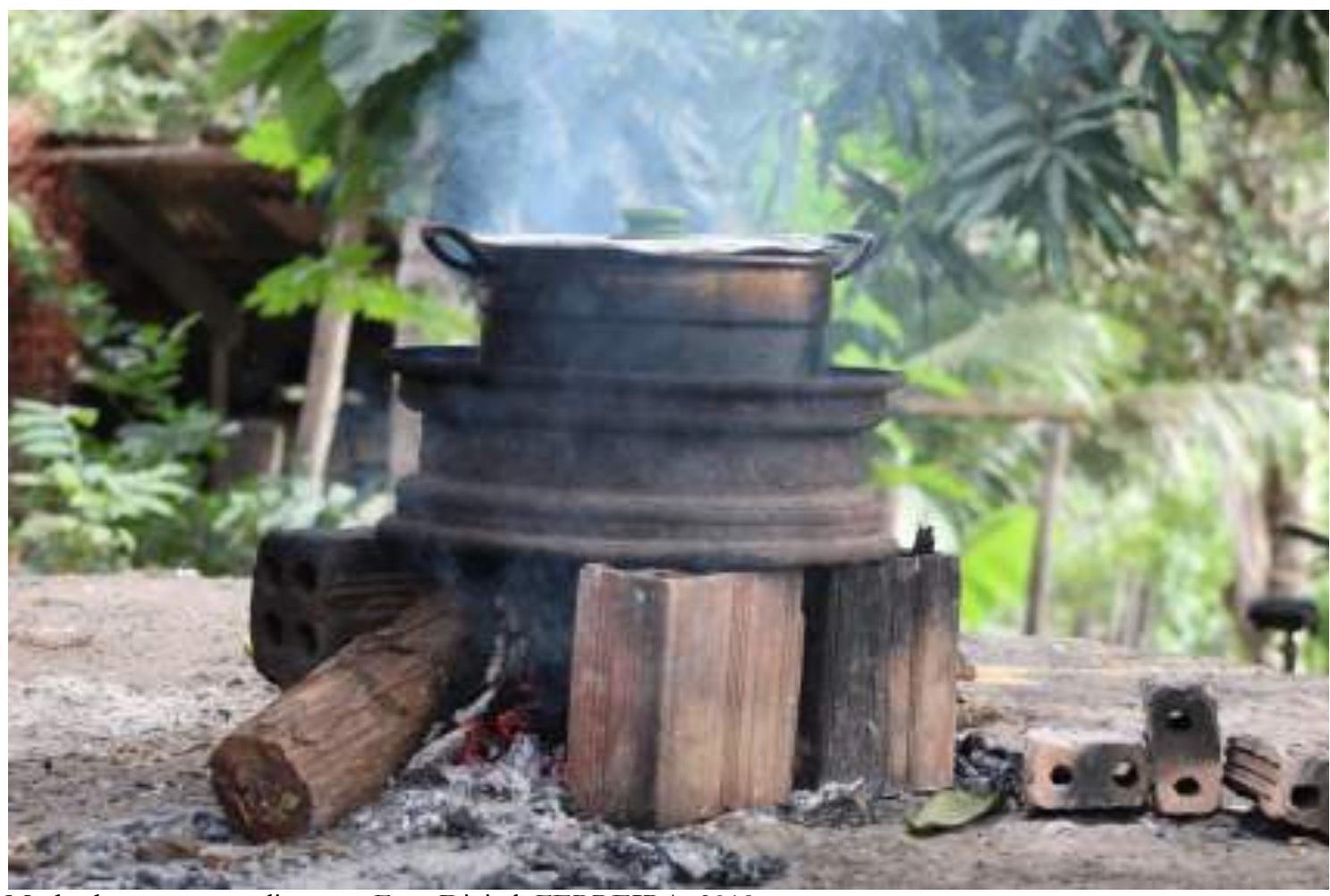

Modo de preparar o alimento. Foto Digital. FERREIRA, 2019. 


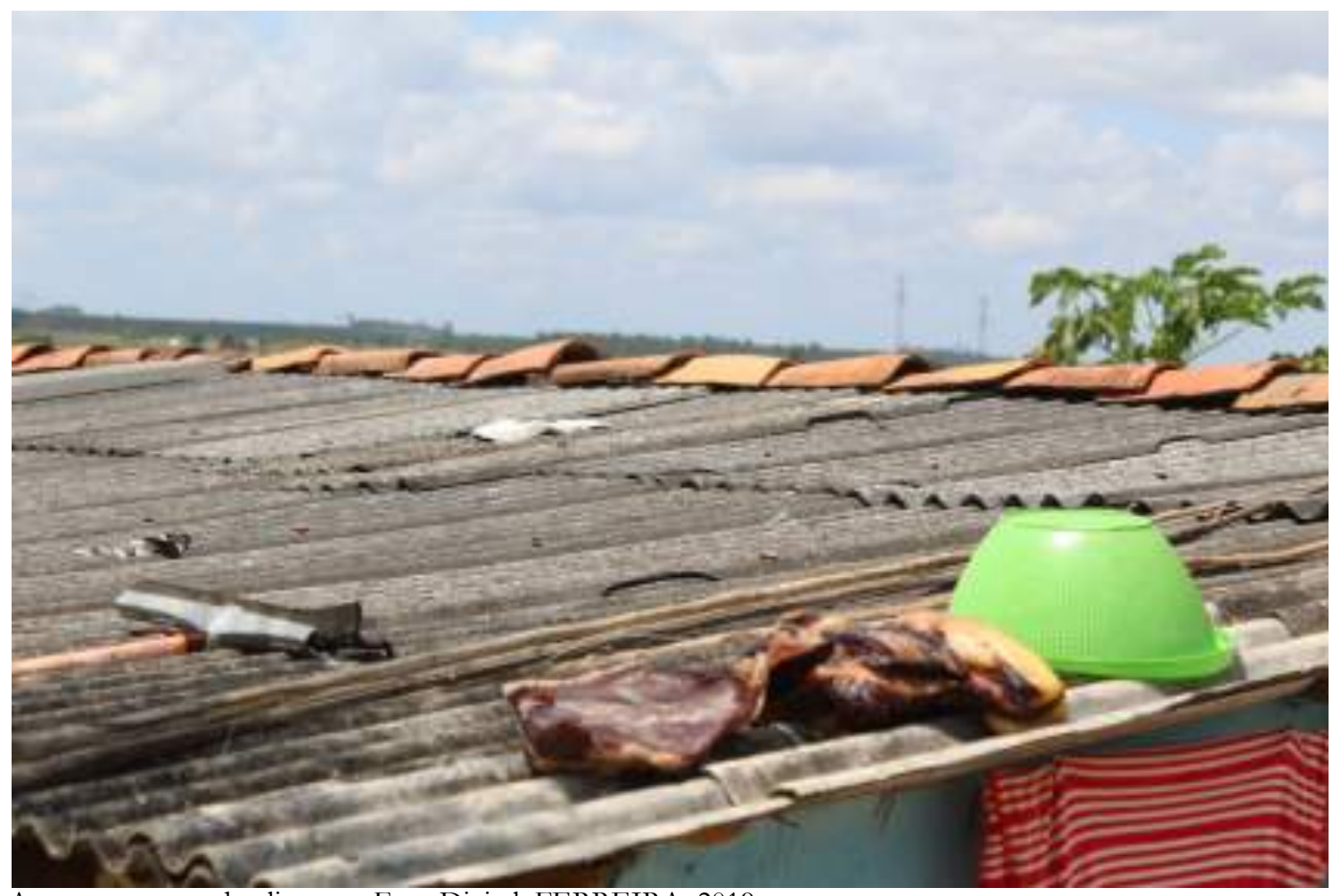

Armazenamento do alimento. Foto Digital. FERREIRA, 2019.

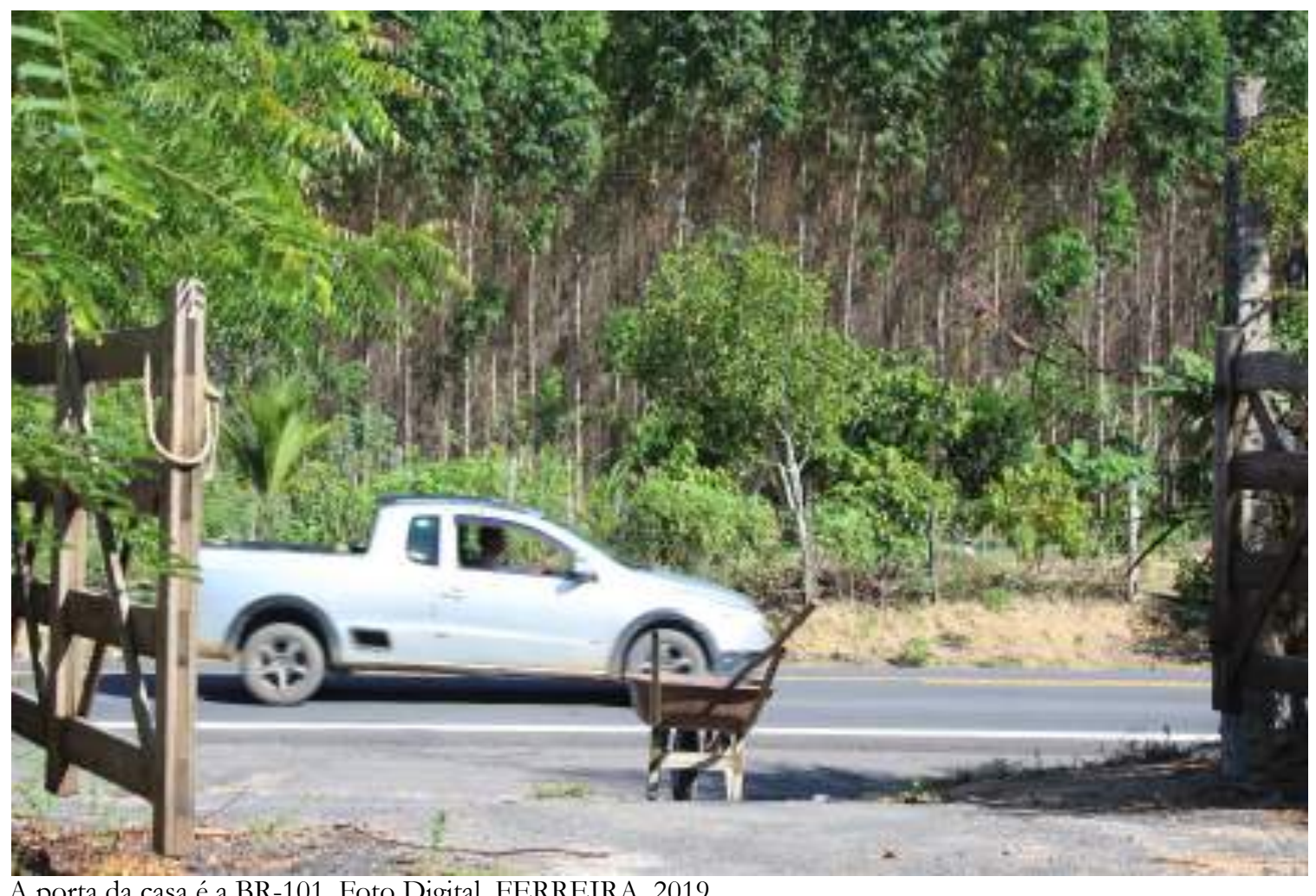

A porta da casa é a BR-101. Foto Digital. FERREIRA, 2019. 


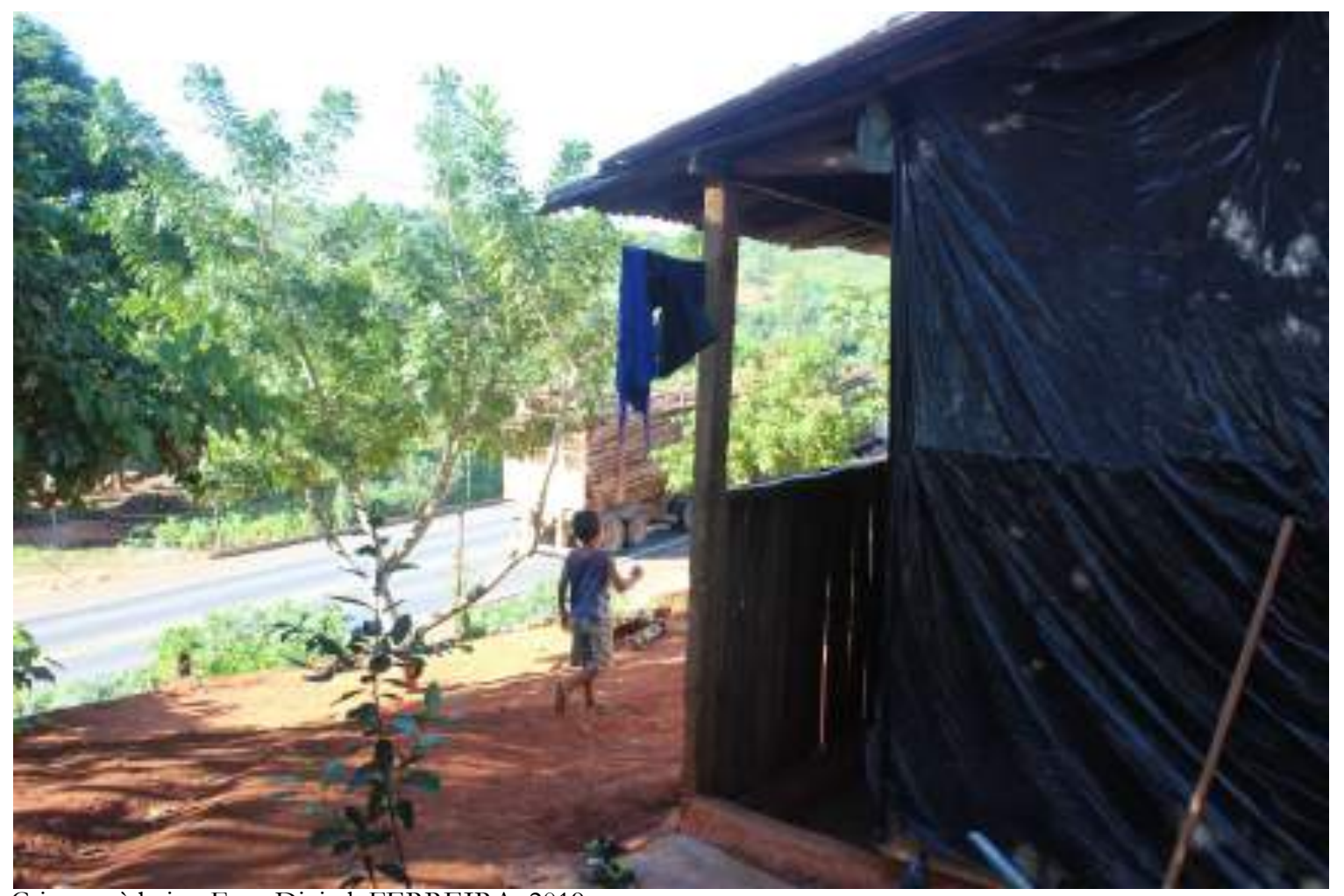

Crianças à beira. Foto Digital. FERREIRA, 2019.

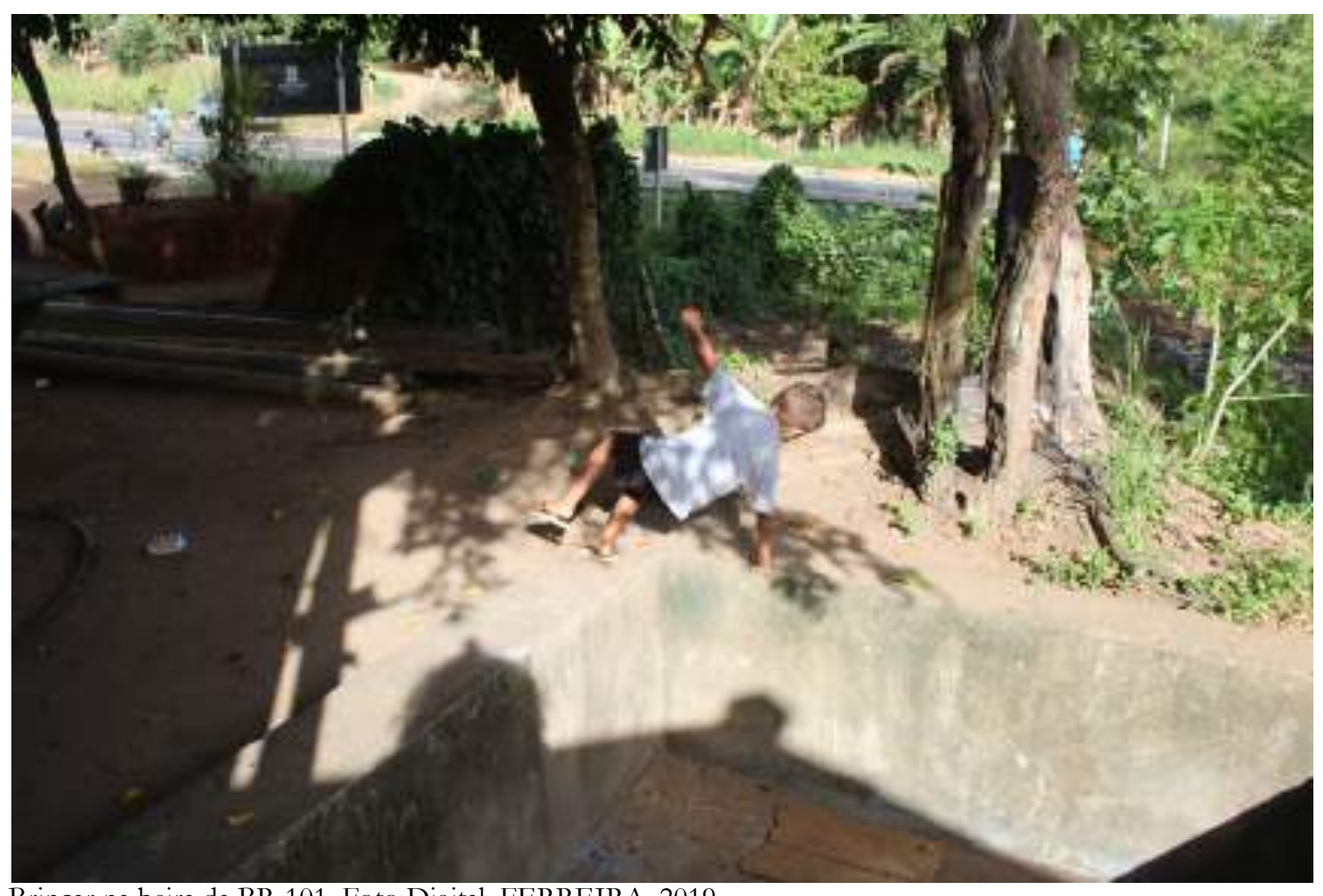

Brincar na beira da BR-101. Foto Digital. FERREIRA, 2019 


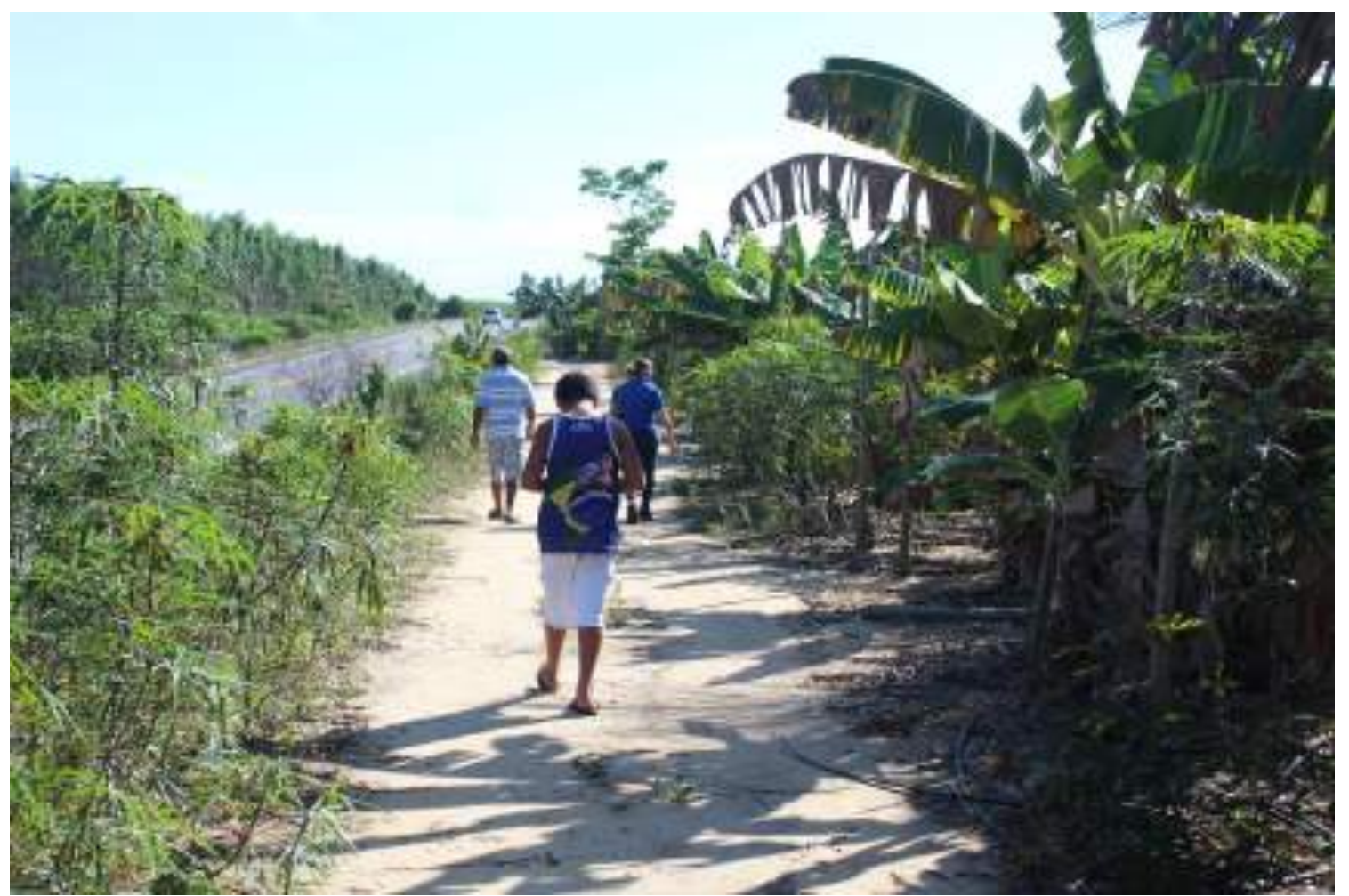

Plantar na beira. Foto Digital. FERREIRA, 2019.

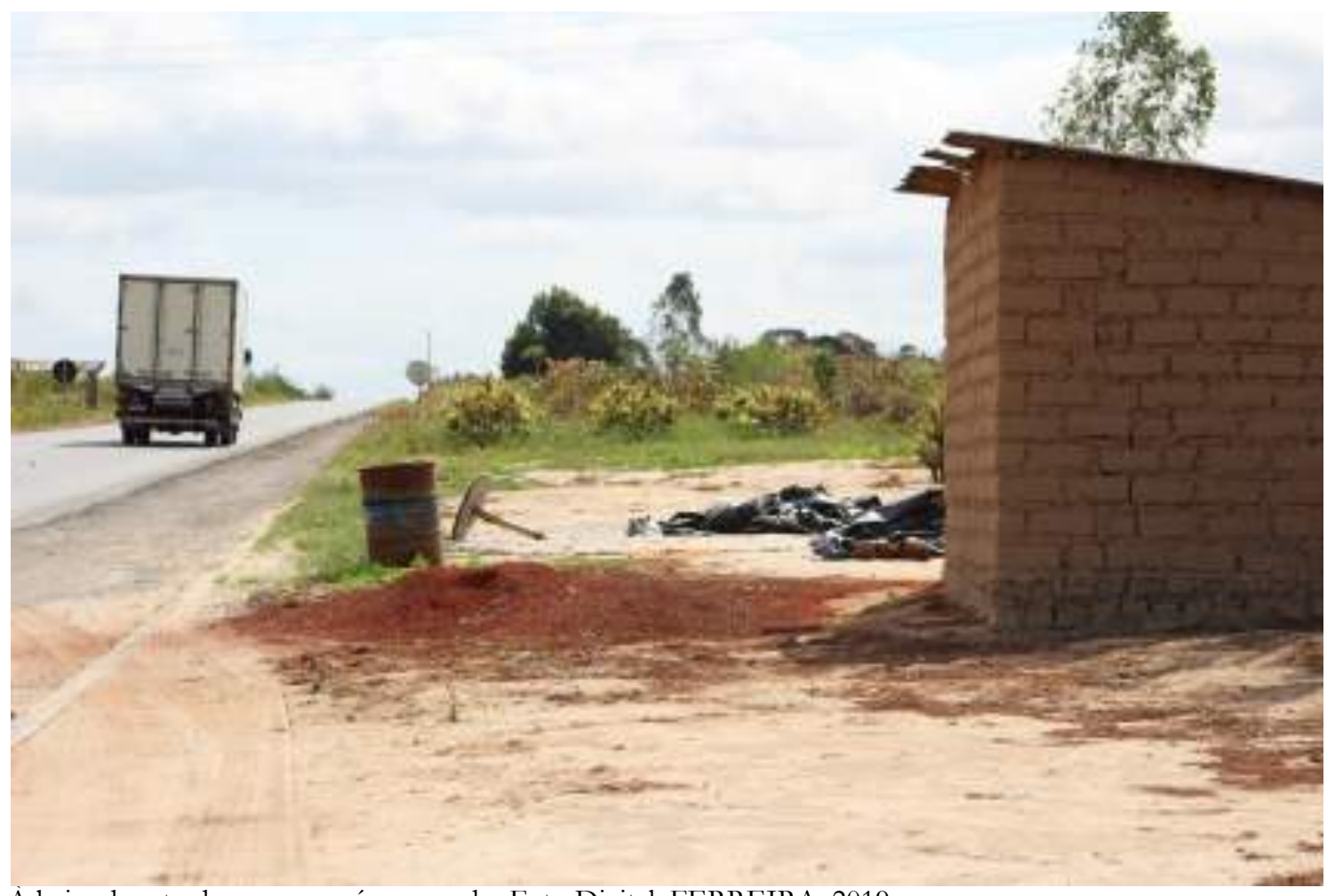

À beira da estrada o urucum é preparado. Foto Digital. FERREIRA, 2019. 


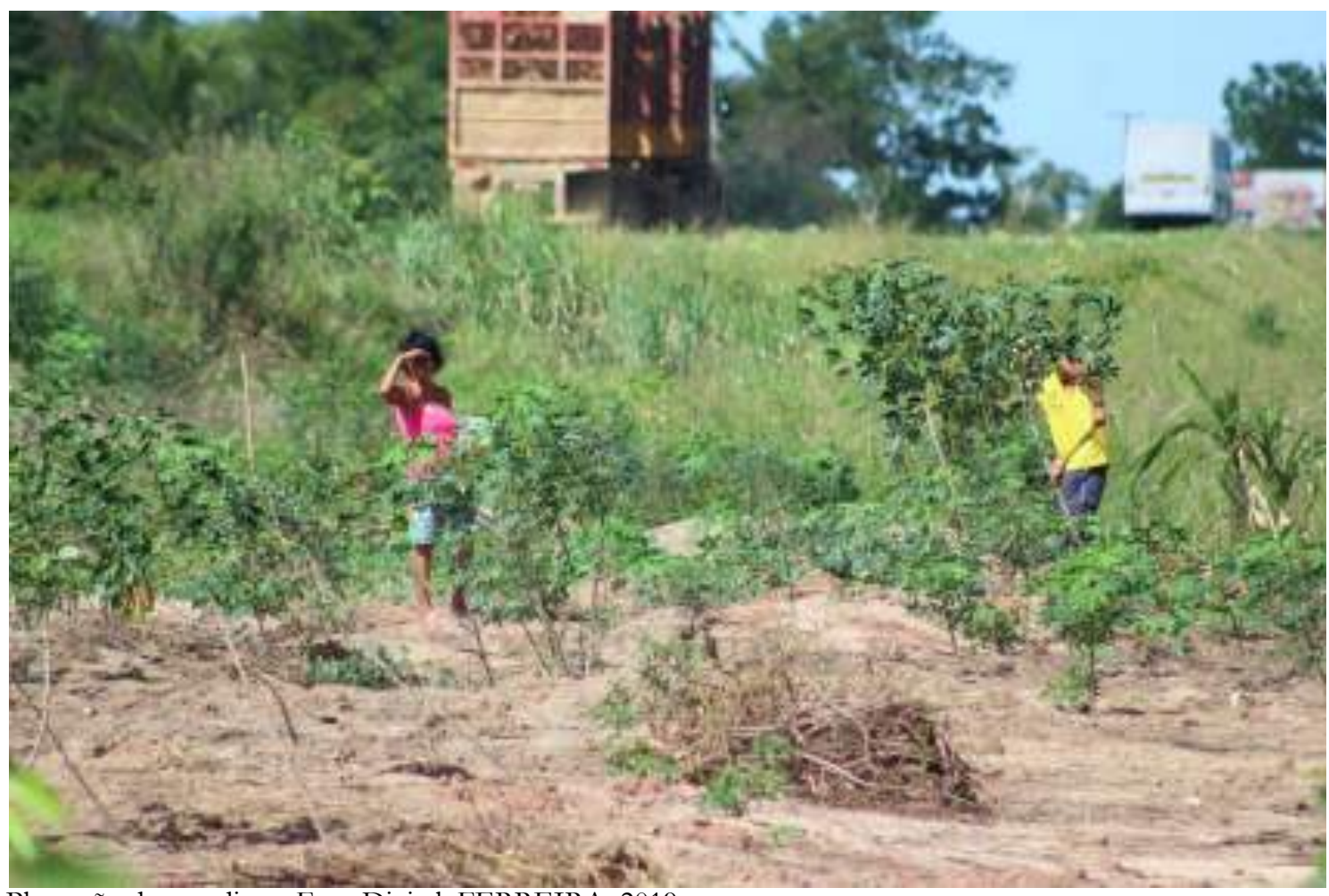

Plantação de mandioca. Foto Digital. FERREIRA, 2019.

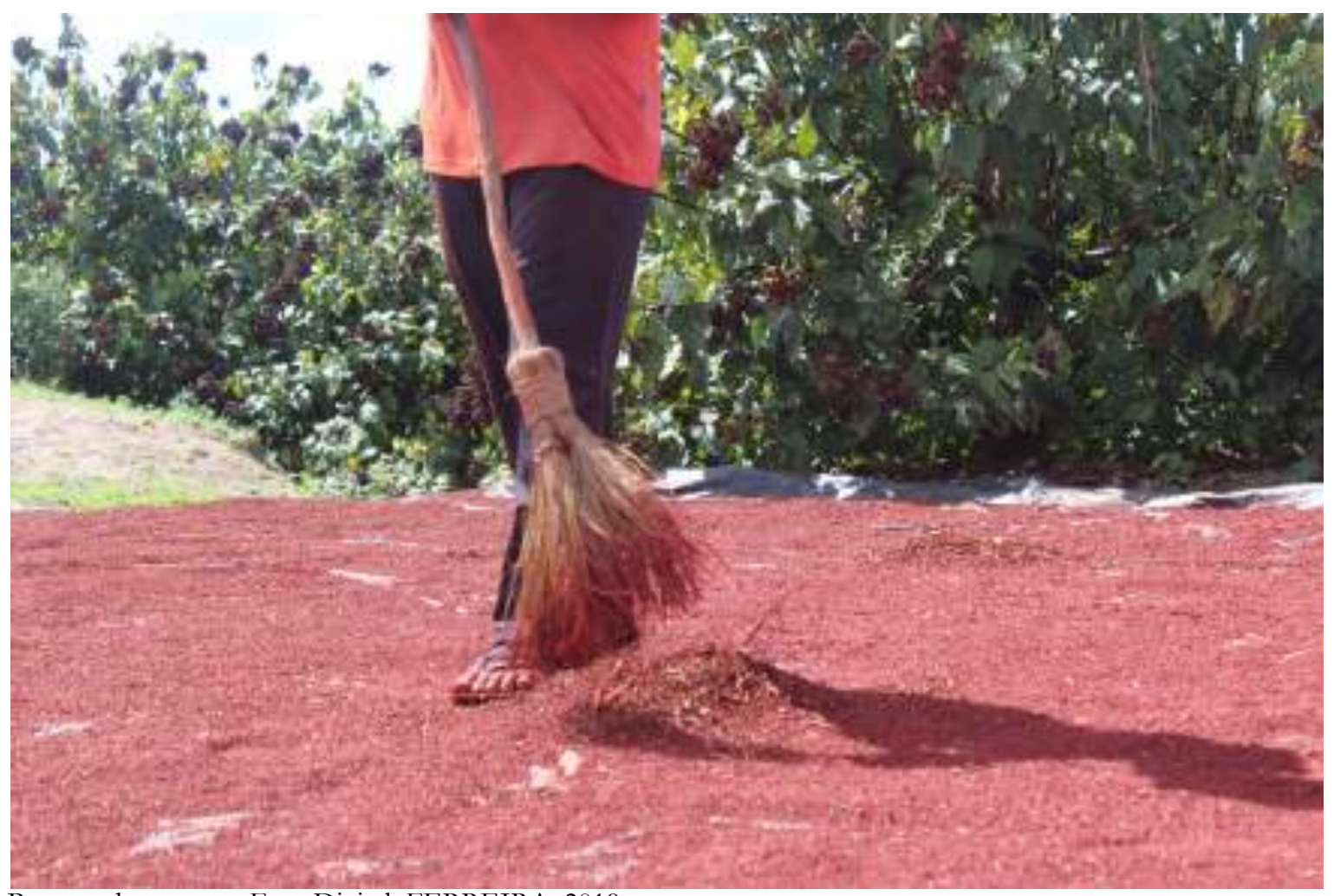

Preparo do urucum. Foto Digital. FERREIRA, 2019. 


\section{Referências}

CANDIDO, Antonio. Os parceiros do Rio Bonito. Coleção Documentos Brasileiros. Rio de Janeiro: José Olympio, 1964.

COSTA, Oneide Andrade da. À beira da vida: vulnerabilidade social dos Beiradeiros no Extremo Sul da Bahia. 2020. 137 fls. Dissertação (Mestrado em Estado e Sociedade). Universidade Federal do Sul da Bahia. Porto Seguro-BA, 2020.

FERREIRA, Ananda da Luz e MARTINS, Herbert Toledo. Infâncias Beiraderias: como é ser criança à beira da BR-101? In: Anais do $43^{\circ}$ Encontro Anual da ANPOCS, de 21 a 25 de outubro de 2019, em Caxambu-MG. ISSN 2177-3092. Disponível por: https://anpocs.com/index.php/encontros/ papers/43-encontro-anual-da-anpocs/st11/st16-8/11724-infancias-beiradeirascomo-e-ser-crianca-a-beira-da-br-101, Acesso em 09 fev. 2020.
MARTINS, Herbert Toledo e CASTRO, Dhanyane Alves. O perfil dos agricultores de beira de estrada do Sul da Bahia. Rio de Janeiro: VII Coniter, 2018.

MONTEIRO, Charles. História, fotografia e cidade: reflexões teórico-metodológicas sobre o campo de pesquisa. MÉTIS: história e cultura, v. 5, n. 9, p. 11-23, jan./jun. 2006.

OLIVEIRA, Francisco Mesquita e JÚNIOR, Magno Vila Castro. Possibilidades do uso da fotografia e da filmagem na pesquisa social qualitativa. In: Revista Ciência e Cultura. Volume 71. Número 4. São Paulo: out/dez2019. Disponível em: http:/ / cienciaecultura.bvs.br/scielo.php?scr ipt $=$ sci_arttext\&pid=S000967252019000400017. Acesso em: 10jul2020 